\title{
Antioxidant Activity of Anthocyanins Extracted from Iraqi Iresine herbstii L. Flowers after Drying and Freezing
}

\author{
Adnan J. M. Al-Fartosy*, Ali Abdulrazzaq Abdulwahid \\ Department of Chemistry, College of Science, University of Basrah, Basrah, Iraq \\ Email: dr.adnanfrtosy@yahoo.com
}

Received 12 February 2015; accepted 27 March 2015; published 31 March 2015

Copyright (C) 2015 by authors and Scientific Research Publishing Inc.

This work is licensed under the Creative Commons Attribution International License (CC BY). http://creativecommons.org/licenses/by/4.0/

c) (i) Open Access

\begin{abstract}
Any processing method that maintains the level of compounds known for their health benefits will be of interest to the food industries. Therefore, the effects of vacuum drying, storage and freezing on the anthocyanin content and their antioxidant properties of Iresine herbstii L. flowers were investigated. The results showed that fresh samples (AEFF) had the highest amount of total anthosyanin content $(8.31 \pm 0.23 \mathrm{mg} / \mathrm{g}$ dry matter, expressed as cyaniding 3-glucoside equivalents), followed by $7.17 \pm 0.12 \mathrm{mg} / \mathrm{g}$ solid content, $13.72 \%$ loss of vacuum dried samples (AEDF). In comparison with fresh samples, total anthocyanins in stored samples for two weeks at $5^{\circ} \mathrm{C}$ (AESF) and frozen samples during $1\left(\mathrm{AEZF}_{1}\right)$ and 3 months $\left(\mathrm{AEZF}_{3}\right)$ of storage were significantly $(\mathrm{P}<0.01)$ reduced to $6.43 \pm 0.24 \mathrm{mg} / \mathrm{g}$ solid content, $22.63 \%$ loss, $5.65 \pm 0.33 \mathrm{mg} / \mathrm{g}$ solid content, $32.01 \%$ loss and $4.71 \pm 0.51 \mathrm{mg} / \mathrm{g}$ solid content, $43.33 \%$ loss, respectively. Anthocyanins from $I$. herbstii $\mathrm{L}$. flowers exhibited a dose-dependent (AEFF $>$ AEDF $>$ AESF $>\mathrm{AEZF}_{1}>\mathrm{AEZF}_{3}$, respectively) antioxidant activity against lipid peroxidation in a linoleic acid model system as well as strong reducing power and ferrous ion chelating abilities. Moreover, the anthocyanins extracted were found to show remarkable scavenging activity on superoxide anion radicals, hydroxyl radicals, hydrogen peroxide, nitric oxide radicals and deoxyribose degradation. Based on the results obtained, we can concluded that the Iresine herbstii L. flowers may be valuable natural antioxidant sources and are potentially applicable in both pharmacy and food industry.
\end{abstract}

\section{Keywords}

Iresine herbstii L. Flowers, Anthocyanin, Frozen Storage, Vacuum Drying, Total Antioxidant Activity, Free Radical Scavenging Activity

\footnotetext{
*Corresponding author.
}

How to cite this paper: Al-Fartosy, A.J.M. and Abdulwahid, A.A. (2015) Antioxidant Activity of Anthocyanins Extracted from Iraqi Iresine herbstii L. Flowers after Drying and Freezing. American Journal of Analytical Chemistry, 6, 382-394. 


\section{Introduction}

Antioxidants are widely used as a food additive to provide protection against oxidative degradation of foods by free radicals. In order to prolong the storage of foods, several synthetic antioxidants such as butylated hydroxytoluene (BHT) and butylated hydroxyanisole (BHA) are used currently. But these substances may be inappropriate for chronic human consumption. Hence the development of alternative antioxidants from natural origin has attracted considerable attention [1]. Some medicinal plants contain various natural antioxidants such as phenolic acids, flavonoids and tannins which are associated with higher antioxidant activity compared with those of dietary plants [2]. Flavonoids such as flavones, isoflavones, flavonones, anthocyanins, and catechins have strong antioxidant capacity [3]. Anthocyanins are polyphenolic compounds responsible for cyanic colors ranging from salmon pink through red and violet to dark blue of most flowers, fruits, leaves and stems. They comprise the largest group of the water-soluble pigments in the plant kingdom [1], and during the last few years it has been an exponential increase in the report of new anthocyanin structures [4]. This can be explained by the use of improved analytical techniques, but the potential use of anthocyanins as health beneficial compounds is another reason for the increased scientific interest in these pigments. They play a definite role in attracting insects in pollination and seed dispersal. They may also have a role in the mechanism of plant resistance to pest attack [1]. Anthocyanins are glycosylated polyhydroxy and polymethoxy derivatives of a flavylium (2- phenylbenzopyrylium) salt. The major glycosidic sugars in the anthocyanin structure are glucose, galactose, rhamnose, and arabinose, while the common anthocyanin aglycones in plants are cyanidin, delphinidin, petunidin, peonidin, pelargonidin and malvidin [5]. Anthocyanins have not been broadly used in foods and beverages, although they have been reported to be safe for use in dietary supplements [6]. Their susceptibility to color deterioration during processing and storage has limited their application as commercial colorants [7]. In fact, much attention has been given to the intrinsic and extrinsic factors affecting pigment stability and color, such as temperature, the presence of light and $\mathrm{pH}$ value [8]. Thermal processes including pasteurization, sterilization or concentration have been implicated in anthocyanin degradation and color loss [9]. Iresine herbstii belongs to Amaranthaceae family and is commonly known as blood leaf, chicken gizzard, beefsteak plant and Herbst's blood leaf (English), Naayurivi (Tamil). Blood leaf, probably first collected in Brazil, is native to tropical South America. But it is also available in the tropical forest in several parts of India and tropical Asia and has multiple applications in different folk medicines. I. herbstii is traditionally used in the Northern Peruvian Andes for black magic with the ritual aim to expel bad spirits from the body [10], and also to diagnose various illnesses. I. herbstii was reported as an additive of ayahuasca [11] and ingredient of San Pedro decoction, with possible hallucinogenic properties [12]. I. herbstii leaves are used in wound healing, anticancer agent, post-labor tonic [13], and externally against skin depurative such as eczemas, sores and pimples [10]. Moreover, the plant is also used in astringent, diuretic, spasmolytic, whooping cough, antimicrobial agent and roots in hemicranias [14]. Leaves and flowers are used in decoction for fever and kidney problems [15] and also as a relaxant and antipyretic [10]. Literature survey revealed that there is no previous report on the antioxidant activity of anthocyanin of $I$. herbstii flowers. Also, because during the drying and storage of frozen flowers, the content of anthocyanin and their antioxidant activities may be altered resulting in a change in antioxidant properties, the goal of this research was to investigate and to compare total anthocyanin and their antioxidant activities in frozen or dried flowers, and to compare them with the values found in fresh flowers. The findings from this work may add to the overall value of the medicinal potential of the plant.

\section{Materials and Methods}

\subsection{Chemicals}

All the chemicals were purchased from Sigma-Aldrich Co. (St. Louis, MO), Riedal de Haën (Germany), Fluka (Switzerland), Randox (United Kingdom) and solvents were from E. Merck (Darmstadt, Germany). All of the reagents were prepared in deionized distilled water to eliminate the contamination of metal ions.

\subsection{Plant Material and Treatments Design}

Flowers of Iresine herbstii L. were collected from the garden of College of Education Pure Science, University of Basra in the month of May, 2012 and the plant was botanically authenticated and voucher specimens (4124) were deposited in the Herbarium of Basra (Iraq, Basra, College of Science, University of Basra). The method of Lohachoompol et al. [16] was modified and adopted to design the treatments of the present study as follow: 
fresh flowers (AEFF) were kept at $5^{\circ} \mathrm{C}$ for up to two weeks before extraction [AESF]. Several batches of flowers were frozen and kept at $-20^{\circ} \mathrm{C}$ up to 3 months. The samples were taken and examined at 1-month $\left(\mathrm{AEZF}_{1}\right)$ and 3-month $\left(\mathrm{AEZF}_{3}\right)$ storage. There were 3 replicates for each sampling point. One batch of flowers weighing 0.5 $\mathrm{kg}$ each was slowly dried (AEDF) using vacuum oven [Binder, Fisher Scientific, USA] at temperature of $40^{\circ} \mathrm{C}$ for 90 minutes, followed by $30^{\circ} \mathrm{C}$ for 120 minutes. Dry matter was determined by drying $5-10 \mathrm{~g}$ flower sample in a vacuum oven at $70^{\circ} \mathrm{C}$, for 72 hours. The dried Flowers were weighed again and the dried matter that remained was determined.

\subsection{Anthocyanin Extraction}

Extraction of anthocyanin from I. herbstii flower (AEIH) was carried out by using the method of [17]. Samples weighing $20 \mathrm{~g}$ of fresh, frozen, and proportionally reduced amounts (based on moisture loss during drying) of dried flowers were blended in a food processor for 1minute with $150 \mathrm{~mL}$ of a mixture of methanol, acetic acid, and deionized distilled water (M:A:W) at a ratio of 25:1:24. Frozen flowers were thawed in a refrigerator (at about $5^{\circ} \mathrm{C}$ ) overnight prior to the extraction. Half of the well-blended solution was centrifuged at $3000 \times \mathrm{g}$ for 20 minutes at $20^{\circ} \mathrm{C}$. The remaining residue from centrifugation after the supernatant was removed was mixed thoroughly with $75 \mathrm{~mL}$ M:A:W, centrifuged, and the supernatant was separated. Each sample was extracted 3 times. The clear liquid from the 3 extractions was evaporated under vacuum at $35^{\circ} \mathrm{C}$. The residue from vacuum evaporation was re-dissolved with $5 \mathrm{~mL}$ of $3 \%(\mathrm{w} / \mathrm{v})$ formic acid in water. This aqueous solution was adsorbed on a $\mathrm{C}_{18}$ Sep-Pak cartridge. The cartridge was washed with $5 \mathrm{~mL}$ of $3 \%(\mathrm{w} / \mathrm{v})$ formic acid in water and eluted with $3.5 \mathrm{~mL}$ of $3 \%(\mathrm{w} / \mathrm{v})$ formic acid in methanol. The anthocyanins eluted from the cartridge were evaporated under vacuum at $35^{\circ} \mathrm{C}$ until dryness. Prior to assay, anthocyanin extracts were dissolved in the mixture of methanol and $0.1 \mathrm{M} \mathrm{HCl}$ at a ratio of 85:15 (MeOH:HCl) to generate the appropriate concentrations.

\subsection{Determination of Total Anthocyanin Content}

The total anthocyanin content was measured using a modified $\mathrm{pH}$ differential method described by Lee et al. [18]. The absorbance anthocyanin at $510 \mathrm{~nm}$ and $700 \mathrm{~nm}$ in different $\mathrm{pH}$ buffers (pH 1.0 and 4.5) was measured simultaneously after 15 minutes of incubation at room temperature. Absorbance readings were made at room temperature against deionized distilled water as blank. Total anthocyanin content was expressed as cyanidin-3-glucoside equivalents and calculated according to the following equation:

$$
\text { Anthocyanin content }(\mathrm{mg} / \mathrm{g} \text { dry matter })=(\mathrm{A} \times \mathrm{Mw} \times \mathrm{DF} / \varepsilon \times 1)
$$

where $\mathrm{A}=\left[\left(\mathrm{A}_{510}-\mathrm{A}_{700}\right) \mathrm{pH} 1.0-\left(\mathrm{A}_{510}-\mathrm{A}_{700}\right) \mathrm{pH}\right.$ 4.5]; Mw (molecular weight) = 449.2 g/mol for cyanidin-3glucoside (cyd-3-glu); DF = dilution factor; $\varepsilon=$ the molar absorptivity $(26,900)$ and $\mathrm{l}=$ path length in $\mathrm{cm}$. This assay was done in triplicate and average values were taken.

\subsection{Antioxidant Activity Study}

\subsubsection{Total Antioxidant Activity}

Total antioxidant activity of $I$. herbstii flower anthocyanin extract (AEIH) was determined by the method of Orak [19]. The anthocyanin extract $(1 \mathrm{~mL})$ was added to linoleic acid solution $(5.0 \mathrm{~mL}, 6 \mathrm{mg} / \mathrm{mL}$ in $99 \%$ methanol) and then incubated for $10 \mathrm{~min}$ at $37^{\circ} \mathrm{C}$. A $0.1 \mathrm{~mL}$ aliquot of the mixture solution was added to $75 \%$ ethanol $(4.7 \mathrm{~mL}), 0.1 \mathrm{M}$ ammonium thiocyanate $(0.1 \mathrm{~mL})$ and $20 \mathrm{mM}$ ferrous chloride $(0.1 \mathrm{~mL})$ in $3.5 \% \mathrm{HCl}$ solution. The reaction was then allowed for $5 \mathrm{~min}$ at $30^{\circ} \mathrm{C}$ in dark. The absorbance was measured at $500 \mathrm{~nm}$. Total antioxidant activity was expressed as a percentage of lipid peroxidation value and calculated according to the following equation:

$$
\% \text { Inhibition }=\left(A_{o}-A\right) \times 100 / A_{0}
$$

where $A_{o}$ was the absorbance of control (blank, without extract) and A was the absorbance in the presence of the extract. This assay was done in triplicate and average values were taken.

\subsubsection{Determination of Reducing Power}

The reducing power of $I$. herbstii flower anthocyanin extract (AEIH) was determined according to the method of 
Oyaizu [20]. The anthocyanin extract $(2.5 \mathrm{~mL}$ ) was mixed with $2.5 \mathrm{ml}$ of $200 \mathrm{mM}$ sodium phosphate buffer (pH 6.6) and $2.5 \mathrm{~mL}$ of $1 \%$ potassium ferricyanide. The mixture was then incubated at $50^{\circ} \mathrm{C}$ for $20 \mathrm{~min}$. After incubation, about $2.5 \mathrm{~mL}$ of $10 \%$ trichloroacetic acid $(\mathrm{w} / \mathrm{v})$ was added. This mixture was centrifuged at $3000 \times \mathrm{g}$ for $10 \mathrm{~min} .5 \mathrm{~mL}$ of the supernatant was mixed with an equal volume of water and $1 \mathrm{~mL}$ of $0.1 \%$ ferric chloride. The absorbance was measured at $700 \mathrm{~nm}$. This assay was done in triplicate and average values were taken. Increased absorbance indicated increased reducing power.

\subsubsection{Superoxide Radical-Scavenging Activity}

Superoxide radicals of $I$. herbstii flower anthocyanin extract (AEIH) were generated by the method of Siddhurajuna et al. [21] with some modifications. All solutions were prepared in 0.05 M phosphate buffer (pH 7.8). The photo induced reactions were performed in aluminium foil-lined box with two $30 \mathrm{~W}$ fluorescent lamps. The distance between the reaction solution and the lamp was adjusted until the intensity of illumination reached about 4000 candelia units. The anthocyanin extract $(1 \mathrm{~mL})$ was mixed with $3 \mathrm{ml}$ of reaction buffer solution (1.3 mm riboflavin, $13 \mathrm{mM}$ methionine, $63 \mu \mathrm{M}$ nitro blue tetrazolium and $100 \mu \mathrm{M}$ EDTA, $\mathrm{pH}$ 7.8). The reaction solution was illuminated for $15 \mathrm{~min}$ at $25^{\circ} \mathrm{C}$. Then the absorbance of the reaction mixture was measured at $560 \mathrm{~nm}$ with a spectrophotometer and the superoxide anion radical scavenging activity was calculated according to the equation (Equation (2)) described in Section 2.5.1. This assay was done in triplicate and average values were taken.

\subsubsection{Hydroxyl Radical Scavenging Activity}

The hydroxyl radical scavenging activity of $I$. herbstii flower anthocyanin extract (AEIH) was determined according to the methods described by Singh et al. [22]. Anthocyanin extracts ( $0.1 \mathrm{~mL}$ were taken in separate test tubes. $1 \mathrm{~mL}$ of iron-EDTA solution (0.1\% ferrous ammonium sulfate and $0.26 \%$ EDTA) followed by $0.5 \mathrm{~mL}$ of DMSO $(0.85 \% \mathrm{v} / \mathrm{v}$ in $0.1 \mathrm{M}$ Phosphate buffer, $\mathrm{pH}$ 7.4) were added to these tubes, and the reaction was initiated by adding $0.5 \mathrm{~mL}$ of $0.22 \%$ ascorbic acid. Test tubes were capped tightly and incubated in a water bath at $80^{\circ} \mathrm{C}-$ $90^{\circ} \mathrm{C}$ for $15 \mathrm{~min}$. The reaction was terminated by the addition of $1 \mathrm{~mL}$ of ice cold TCA $(17.5 \% \mathrm{w} / \mathrm{v})$. To that 3 $\mathrm{mL}$ of Nash reagent (75 g of ammonium acetate, $3 \mathrm{~mL}$ of glacial acetic acid, and $2 \mathrm{~mL}$ of acetyl acetone were mixed and raised to $1 \mathrm{~L}$ with deionized distilled water) was added to all of the tubes and left at room temperature for $15 \mathrm{~min}$ for the color development. The intensity of the yellow color formed was measured spectrophotometrically at $412 \mathrm{~nm}$. The hydroxyl radical scavenging activity was calculated according to the equation (Equation (2)) described in Section 2.5.1. This assay was done in triplicate and average values were taken.

\subsubsection{Hydrogen Peroxide Scavenging Activity}

Hydrogen peroxide scavenging activity of $I$. herbstii flower anthocyanin extract (AEIH) was determined using the method described by Akinpelu et al. [23]. Anthocyanin extracts [0.1 mL] was mixed with $0.6 \mathrm{~mL}$ of $4 \mathrm{mM}$ $\mathrm{H}_{2} \mathrm{O}_{2}$ solution prepared in phosphate buffer $(0.1 \mathrm{M} \mathrm{pH}$ 7.4) and incubated for $10 \mathrm{~min}$. The absorbance of the solution was taken at $230 \mathrm{~nm}$ against blank solution containing the $\mathrm{H}_{2} \mathrm{O}_{2}$ without plant extract. All the analyses were performed in triplicate and results were averaged. The hydrogen peroxide scavenging activity was calculated according to the equation (Equation (2)) described in Section 2.5.1. This assay was done in triplicate and average values were taken.

\subsubsection{Nitric Oxide Radical Scavenging Activity}

Nitric oxide generated from sodium nitroprosside was measured by the Griess Illosvoy reagent method Susuanta et al. [24]. About $2 \mathrm{~mL}$ of $10 \mathrm{mM}$ sodium nitroprosside in $0.5 \mathrm{~mL}$ phosphate buffer saline (pH 7.4) was mixed with $0.5 \mathrm{~mL}$ of anthocyanin extract and the mixture incubated at $25^{\circ} \mathrm{C}$ for $150 \mathrm{~min}$. From the incubated mixture, $0.5 \mathrm{~mL}$ was taken out and added into $1 \mathrm{~mL}$ sulfanilic acid reagent (33\% in $20 \%$ glacial acetic acid) and incubated at room temperature for $5 \mathrm{~min}$. Finally, $1 \mathrm{~mL}$ naphthyl ethylenediamine dihydrochloride $(0.1 \% \mathrm{w} / \mathrm{v}) \mathrm{was}$ mixed and incubated at room temperature for $30 \mathrm{~min}$. The nitric oxide produced was measured colorimetrically at $540 \mathrm{~nm}$. The nitric oxide radicals scavenging activity was calculated according to the equation (Equation (2)) described in Section 2.5.1. This assay was done in triplicate and average values were taken.

\subsubsection{Metal Chelating Activity}

The chelating of ferrous ions by the I. herbstii flower anthocyanin extract (AEIH) was estimated by the method 
of Ponmozhi et al. [1] with slight modification and compared with EDTA, BHT and ascorbic acid standards. About $100 \mu \mathrm{l}$ of standard and anthocyanin extract were added to a solution of $100 \mu \mathrm{L}$ Ferric chloride (1 mM). The reaction was initiated by the addition of $250 \mu \mathrm{L}$ ferrozine $(1 \mathrm{Mm})$. The mixture was finally quantified to 1.3 $\mathrm{mL}$ with methanol, shaken vigorously and left standing at room temperature for $10 \mathrm{~min}$. After the mixture had reached equilibrium, the absorbance of the solution was measured spectrophotometrically at $562 \mathrm{~nm}$. The lower absorbance at $562 \mathrm{~nm}$ indicated stronger chelating effect. The percentage inhibition of ferrous-ferrozine complex formation was calculated according to the equation (Equation (2)) described in Section 2.5.1. This assay was done in triplicate and average values were taken.

\subsubsection{Inhibitory Effect on Deoxyribose Degradation}

Inhibitory effect of $I$. herbstii flower anthocyanin extract (AEIH) on deoxyribose degradation was determined and hydroxyl radicals (referred to as non-site-specific scavenging assay) or antioxidants and iron ions (referred to as site-specific scavenging assay), described by Lee et al. [25]. For the non site specific scavenging activity assay, anthocyanin extracts $(0.1 \mathrm{~mL})$ was mixed with $1 \mathrm{~mL}$ of reaction buffer $(100 \mu \mathrm{M} \mathrm{FeCl}, 104 \mu \mathrm{M} \mathrm{EDTA}$, $1.5 \mathrm{mM} \mathrm{H}_{2} \mathrm{O}_{2}, 2.5 \mathrm{mM}$ deoxyribose and $100 \mu \mathrm{M} \mathrm{L}$-ascorbic acid $\mathrm{pH} 7.4$ ) and incubated for $1 \mathrm{~h}$ at $37^{\circ} \mathrm{C}$. About 1 $\mathrm{mL}$ of $0.5 \%$ 2-thiobarbituric acid in $0.025 \mathrm{M} \mathrm{NaOH}$ and $1 \mathrm{~mL}$ of $2.8 \%$ trichloroacetic acid were added to the mixture and it was heated for $30 \mathrm{~min}$ at $80^{\circ} \mathrm{C}$. The mixture was cooled on ice and the absorbance was measured at $532 \mathrm{~nm}$. Site-specific scavenging activity, which represented the ability of anthocycanins to cheated iron ions and interferes with hydroxyl radical generation, was measured using the same reaction buffer without EDTA. The inhibitory effect of the anthocyanins on deoxyribose degradation was calculated according to the equation (Equation (2)) described in Section 2.5.1. This assay was done in triplicate and average values were taken.

\subsection{Statistical Analysis}

The data were expressed as mean values \pm SEM and tested with analysis of variance followed by Dunnett's t-test. P-values $<0.05,0.01$ were considered to be statistically significant.

\section{Results and Discussion}

\subsection{Total Anthocyanins}

The total anthocyanins contents in fresh flowers after drying and during the 3 months storage are shown in Table 1. Fresh samples (AEFF) had the highest total anthocyanin content $(8.31 \pm 0.23 \mathrm{mg} / \mathrm{g})$, while frozen samples $\left(\mathrm{AEZF}_{3}\right)$ had the lowest value $(4.71 \pm 0.51 \mathrm{mg} / \mathrm{g})$. The total anthocyanin content in decreasing order was Fresh sample $>$ Vacuum dried sample $>$ Storage sample 2-week at $5^{\circ} \mathrm{C}>$ Frozen sample for 1 month $>$ Frozen sample for 3 month. Interestingly, both vacuum dried and stored frozen conditions are led to deterioration of these compounds. In dried sample (AEDF) the anthocyanins content was less $(\mathrm{P}<0.05)$ in fresh flowers and the percentage of loss of anthocyanins was $22.63 \%$. Anthocyanin leakage might happen due to dewaxing, which was caused by stirring and soaking during the osmotic pretreatment. This permitted some leakage from the exposed edges or undersurface of the torn skin to the osmotic solution that caused anthocyanin loss before the drying step. Also, the thermal processing destroyed some anthocyanins [26]. According to our results, significantly decreases $(\mathrm{P}<0.01)$ of anthocyanins were started immediately after freezing. During the kept of flowers samples at $5^{\circ} \mathrm{C}$ for 2 weeks [AESF] before extraction, there was a slow degradation of anthocyanins. The value of percentage

Table 1. Effect of drying and freezing on anthocyanin contents of Iresine herbstii L. flowers (AIHF) in evaluated samples.

\begin{tabular}{|c|c|c|c|}
\hline Treatments & Symbol & Total anthocyanin mg/g dry matter & $\%$ loss of anthocyanin \\
\hline Fresh flower & $\mathrm{AEFF}$ & $8.31 \pm 0.23$ & - \\
\hline Dried flower & AEDF & $7.17 \pm 0.12^{*}$ & 13.72 \\
\hline Flower 2-week storage at $5^{\circ} \mathrm{C}$ & AESF & $6.43 \pm 0.24^{* *}$ & 22.63 \\
\hline Flower stored frozen for 1 month & $\mathrm{AEZF}_{1}$ & $5.65 \pm 0.33^{* *}$ & 32.01 \\
\hline Flower stored frozen for 3 month & $\mathrm{AEZF}_{3}$ & $4.71 \pm 0.51^{* *}$ & 43.33 \\
\hline
\end{tabular}

Total anthocyanin as cyanidin-3-glucoside equivalent, values are mean $\pm \mathrm{SEM},{ }^{*} \mathrm{P}<0.05,{ }^{* *} \mathrm{P}<0.01$, Dunnet test as compared to fresh flower group. 
degradation was proportional depending on the percentage of soft flowers in the whole sample. Anthocyanins contents of frozen samples for 1 month $\left(\mathrm{AEZF}_{1}\right)$ and 3 month $\left(\mathrm{AEZF}_{3}\right)$ were found significantly decreased $(\mathrm{P}<$ 0.01 ) with compared to fresh sample (AEFF). This indicates that anthocyanins degradation rate was accelerated at longer storage. Probably, significant decrease of investigated compounds was due to water content in nonfrozen state. Activity and enzymatic reaction rate reached maximum values in the layers of liquid water in frozen fruits. Perhaps, this phenomenon contributes to the modification of chemical compounds, including biologically active substances. In frozen products the enzymatic reactions are slow, but not completely blocked [27].

\subsection{Antioxidant Activity Study}

\subsubsection{Total Antioxidant Activity}

The total antioxidant activity of $I$. herbstii flower anthocyanin extract (AEIH) was determined by peroxidation of linoleic acid using ferric thiocyanate method. During linoleic acid peroxidation, peroxides were formed and these compounds oxidized $\mathrm{Fe}^{2+}$ to $\mathrm{Fe}^{3+}$. The $\mathrm{Fe}^{3+}$ ion forms a complex with $\mathrm{SCN}^{-}$, which had a maximum absorbance at $500 \mathrm{~nm}$ [28]. Thus a high absorbance value was an indication of high peroxide formation during the emulsion incubation inhibits peroxidation of linoleic acid and reduces formation of hydrogen peroxide. According to the results displayed in Figure 1. Total antioxidant activity increase with increase in the amount of anthocyanins contents. Therefore, AEFF had a significant $(\mathrm{P}<0.01)$ higher inhibitory effect on peroxidation of linoleic acid than other extracts. The order of inhibition was AEFF (78.12\%) > AEDF (69.23\%) > AESF $(60.11 \%)>\mathrm{AEZF}_{1}(53.33 \%)>\mathrm{AEZF}_{3}(48.13 \%)$, respectively. However, both fresh and vacuum dried samples gave higher antioxidant activity compared with storage sample. The use of a vacuum may allow water to evaporate at lower temperatures and the absence of oxygen in the environment helps to reduce potential oxidation resulting in the preservation of antioxidant components [29]. The results indicate that anthocyanins can significantly powerful natural antioxidant. The higher antioxidant activity in various plants has a considerable role in the prevention of various degenerative diseases by reducing free radical-induced oxidative damage [30].

\subsubsection{Reducing Power}

Furthermore, the reducing power of the extractable anthocyanins from I. herbstii flower (AEIH) is presented in Figure 2. The trend of the reducing capacity of the extracts was concentration dependent. At the total anthocyanin content ( $8.31 \pm 0.23 \mathrm{mg} / \mathrm{g}$ ), the result revealed that AEFF sample of flower of $I$. herbstii had a significant (P $<0.01$ ) higher reducing power followed by AEDF and AESF while $\mathrm{AEZF}_{1}$ and $\mathrm{AEZF}_{3}$ samples had the least. The antioxidant activities of putative antioxidants have been attributed to various mechanisms such as prevention of chain initiation, binding of transition metal ion catalysts, decomposition of peroxides, prevention of continued proton abstraction, and radical scavenging [31]. The reducing power as typified by the ability of the plant

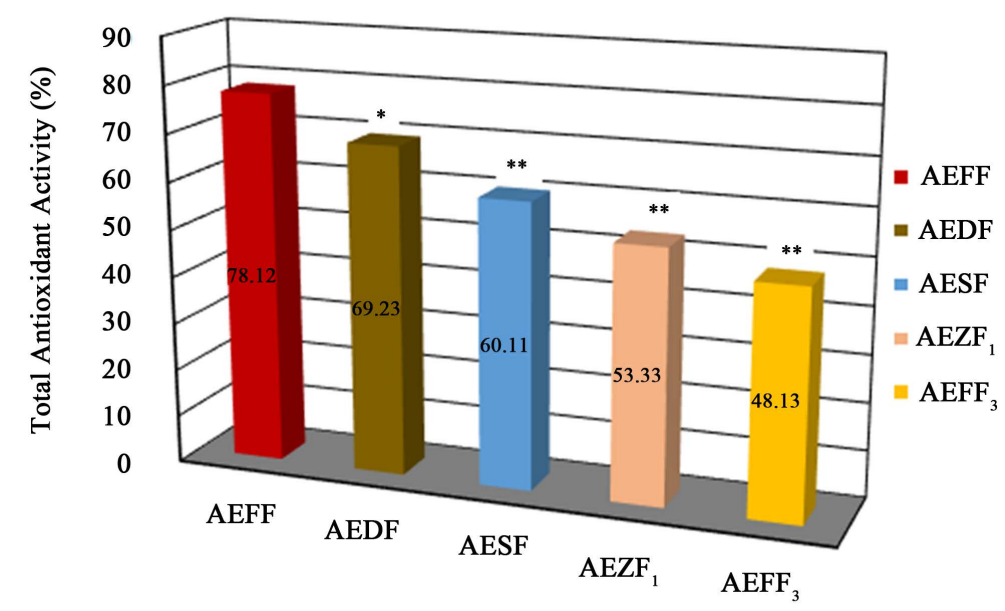

Anthocyanin Extracts

Figure 1. Total antioxidant activity of anthocyanin contents of Iresine herbstii L. flowers $(\mathrm{AEIH})$. Values are mean $\pm \mathrm{SEM},{ }^{*} \mathrm{P}<0.05,{ }^{* *} \mathrm{P}<0.01$, Dunnet test as compared to fresh flower group. 


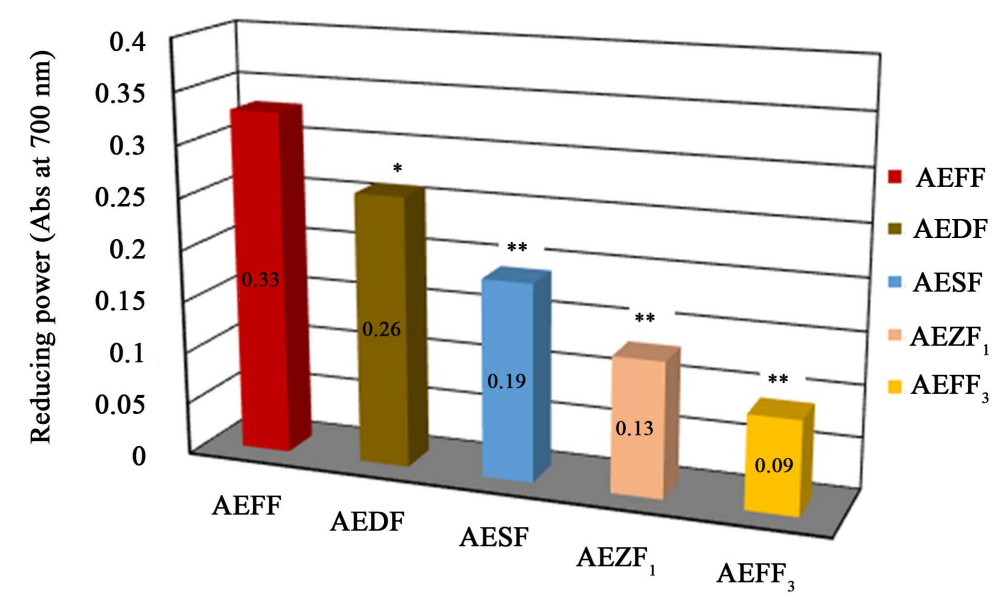

Anthocyanin Extracts

Figure 2. Reducing power activity of anthocyanin contents of Iresine herbstii L. flowers $(\mathrm{AEIH})$. Values are mean \pm SEM, ${ }^{*} \mathrm{P}<0.05,{ }^{* * *} \mathrm{P}<0.01$, Dunnet test as compared to fresh flower group.

extracts to reduce $\mathrm{Fe}^{3+}$ to $\mathrm{Fe}^{2+}$ is a potent antioxidation defense mechanism, and two mechanisms available to effect this reducing power is by electron transfer and hydrogen atom transfer [32]. Allhorn et al. [33] reported that the reducing property can be a novel antioxidation defense mechanism, possibly through the ability of the antioxidant compound to reduce transition metals. Polyphenolics in the anthocyanin extracts appear to function as good electron and hydrogen atoms donor and therefore should be able to terminate radical chain reaction by converting free radicals to more stable products.

\subsubsection{Determination of Superoxide Radical Scavenging Activity}

Superoxide anion radicals are produced by a number of cellular reactions, including various enzymes systems such as lipooxygenase, peroxidase, NADPH oxidase and xanthain oxidase. Superoxide anions place an important role in plant tissue and are involved in the formation of other cell damaging free radicals [34]. In the present study, superoxide radical can be generated by illuminating a solution containing riboflavin. Superoxide anion radical reduces NBT to a blue colored formazan that is measured at $560 \mathrm{~nm}$. The decrease of absorbance at 560 $\mathrm{nm}$ with antioxidants thus indicates the consumption of superoxide anion in the reaction mixture. Based on the results obtained as represented in the Figure 3 is clear that Fresh samples (AEFF) of $I$. herbstii flower has better superoxide scavenging activity as compare to the other extracts, which may be again due to the higher amount of total anthocyanin content. The superoxide radical scavenging ability of the extracts can be ranked in the order $\operatorname{AEFF}(76.25 \%)>\operatorname{AEDF}(65.18 \%)>\operatorname{AESF}(56.13 \%)>\operatorname{AEZF}_{1}$ (41.24\%) > $\operatorname{AEZF}_{3}$ (33.19\%), respectively. Further superoxides are also known to indirectly initiate lipid peroxidation as a result of $\mathrm{H}_{2} \mathrm{O}_{2}$ formation, creating precursor of hydroxyl radicals [35]. Our result clearly shows that antioxidant activity of anthocyanin extracted from I. herbstii flower (AEIH) is also related to ability to scavenge superoxides.

\subsubsection{Hydroxyl Radical Scavenging Activity}

The hydroxyl radical is extremely reactive free radicals formed in biological system and has been implicated as a higher damaging species in free radical pathology. Capable of damaging almost every molecule found in living cells. This species is considered to be one of the quick initiators of the lipid peroxidation process, abstracting hydrogen atoms from unsaturated fatty acids [1]. The scavenging of hydroxyl radical by anthocyanin extracts of I. herbstii flower (AEIH) was increased in a dose dependent manner, as illustrated in Figure 4. The scavenging percentage achieved $(71.38 \%)$ at the higher amount anthocyanin extract (AEFF). This was followed by AEDF (62.21\%), AESF (54.17\%), AEZF 1 (39.13\%) samples whereas, $\mathrm{AEZF}_{3}$ samples showed the least inhibition (27.18\%). This is similar to the observation of several others who have reported a dose-dependent activity in other foods such as sesame coat, pomegranate peel and seeds and grapes pomace [36] [22]. The ability of anthocyanin extracts to quench hydroxyl radical seems to be directly related in to prevention of propagation of the 


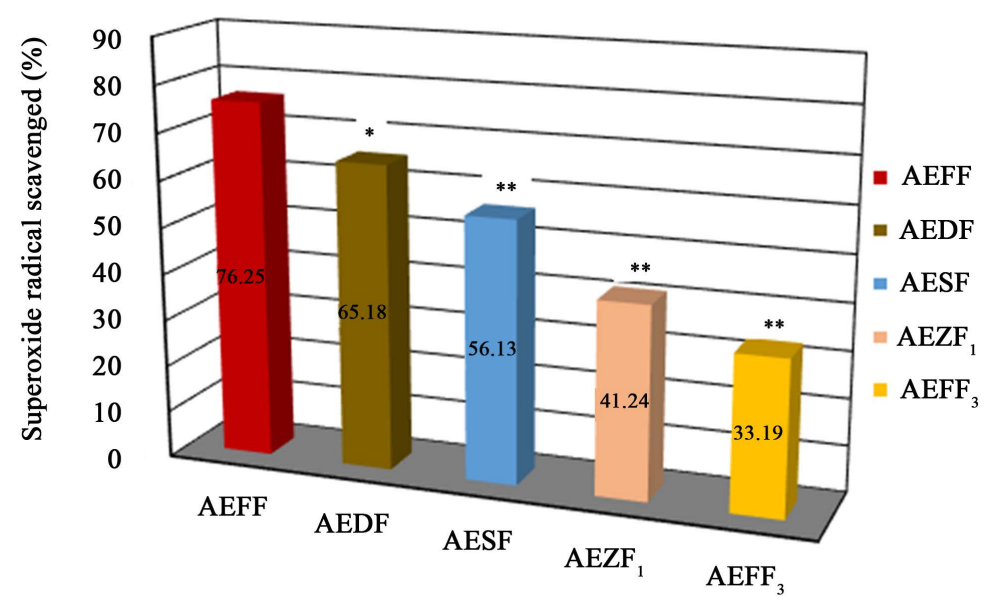

Anthocyanin Extracts

Figure 3. Superoxide scavenging activity of anthocyanin contents of Iresine herbstii L. flowers (AEIH). Values are mean $\pm \mathrm{SEM},{ }^{*} \mathrm{P}<0.05,{ }^{* *} \mathrm{P}<0.01$, Dunnet test as compared to fresh flower group.

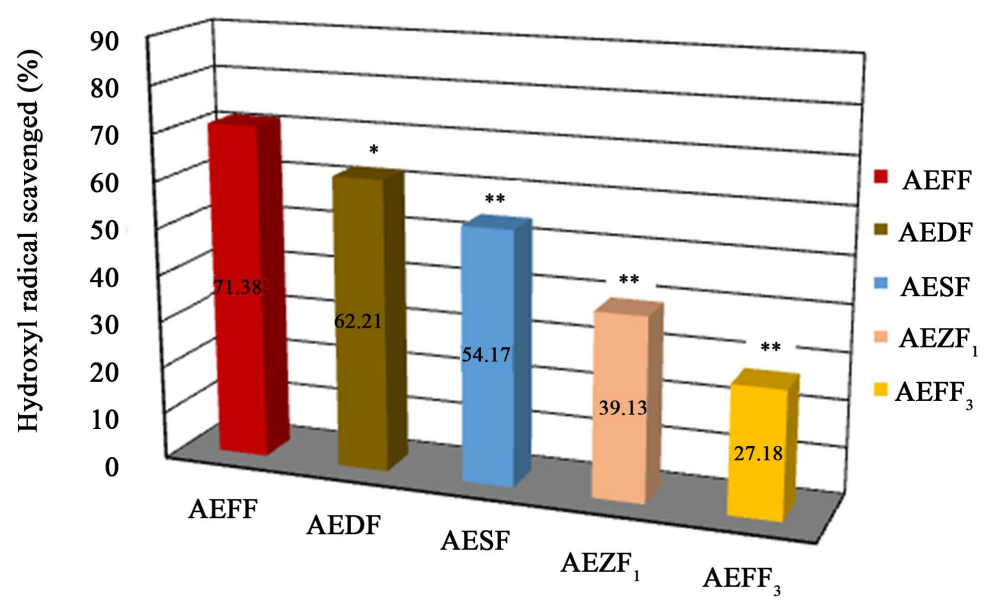

Anthocyanin Extracts

Figure 4. Hydroxyl radical scavenging activity of anthocyanin contents of Iresine herbstii L. flowers (AEIH). Values are mean $\pm \mathrm{SEM},{ }^{*} \mathrm{P}<0.05,{ }^{* *} \mathrm{P}<$ 0.01 , Dunnet test as compared to fresh flower group.

process of lipid peroxidation. The anthocyanin extract (AEFF) seems to be a good scavenger of active oxygen species, thus reducing rate of chain reaction.

\subsubsection{Hydrogen Peroxide Scavenging Activity}

The measurement of $\mathrm{H}_{2} \mathrm{O}_{2}$-scavenging activity is one of the useful methods of determining the ability of antioxidants to decrease the level of pro-oxidants such as $\mathrm{H}_{2} \mathrm{O}_{2}$ [37]. It can cross membranes and may slowly oxidize a number of compounds. Hydrogen peroxide itself is not very reactive, but sometimes, it can be toxic to cells because of rise in the hydroxyl radicals in the cells [38]. As shown in Figure 5, the anthocyanin extracts also demonstrated hydrogen peroxide decomposition activity in a concentration-dependent manner. The frozen samples $\left(\mathrm{AEZF}_{3}\right)$ of $I$. herbstii L. flowers at $\left(4.71 \pm 0.51 \mathrm{mg} / \mathrm{g}\right.$ ) could reach more than $(25.34 \%) \mathrm{H}_{2} \mathrm{O}_{2}$ scavenging activity, while the best effect [up to 59.13\%] was observed at higher amount [8.31 $\pm 0.23 \mathrm{mg} / \mathrm{g}$ ] fresh samples (AEFF). Again, the hydrogen peroxide scavenging activity of the extracts can be ranked in the order AEFF (59.13\%) > AEDF $(51.09 \%)>\operatorname{AESF}(47.15 \%)>\operatorname{AEZF}_{1}(38.23 \%)>\operatorname{AEZF}_{3}$ (25.34\%), respectively. These results showed that fresh samples (AEFF) had effective $\mathrm{H}_{2} \mathrm{O}_{2}$ scavenging activity. This ability to scavenge hydro- 


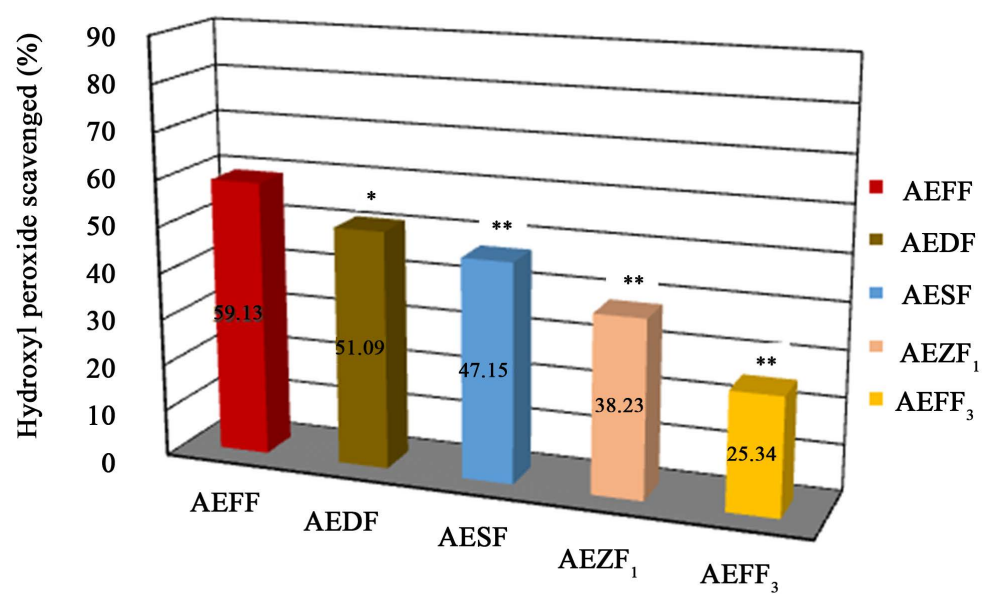

Anthocyanin Extracts

Figure 5. Hydrogen peroxide radical scavenging activity of anthocyanin contents of Iresine herbstii L. flowers (AEIH). Values are mean \pm SEM, ${ }^{*} \mathrm{P}<$ $0.05,{ }^{* *} \mathrm{P}<0.01$, Dunnet test as compared to fresh flower group.

gen peroxide could be an efficient assessment method to evaluate antioxidant property of $I$. herbstii flower anthocyanin extract (AEIH).

\subsubsection{Nitric Oxide Radical Scavenging Activity}

Nitric oxide [NO] radical is generated from sodium nitroprusside at physiological $\mathrm{pH}$. It is a highly reactive compound that is capable of changing the structural and functional behavior of many cellular components [39]. The anthocyanin extracts of $I$. herbstii flower (AEIH) inhibited nitric oxide radical in a concentration dependent manner (Figure 6). At a concentration of $8.31 \mathrm{mg} / \mathrm{g}$, the percentage inhibition of nitric oxide radical was maximum for AEFF extract with $34.04 \%$. The nitric oxide radical scavenging activity in decreasing order was AEFF (34.04\%) > AEDF (30.02\%) > AESF (26.15\%) $>\mathrm{AEZF}_{1}(22.14 \%)>\mathrm{AEZF}_{3}(19.07 \%)$. Nitric oxide is free radical produced in biological cells, involved in regulation of various physiological processes. Nitric oxide is very unstable species under aerobic conditions. It reacts with oxygen to produce stable product nitrate and nitrite through intermediates $\mathrm{NO}_{2}, \mathrm{~N}_{2} \mathrm{O}_{4}$ and $\mathrm{N}_{3} \mathrm{O}_{4}$. In present study, the inhibitory potentials of the extracts against $\mathrm{NO}$ radical can be attributed to their ability to compete with oxygen and its derivatives [33].

\subsubsection{Metal Chelating Activity}

Minimizing $\mathrm{Fe}^{2+}$ may afford protection against oxidative damage by inhibiting the production of ROS and lipid peroxidation [30]. Thus, the ability of antioxidants to form insoluble metal complexes with ferrous ion [or] to generate steric hindrance that prevent interaction between metal and lipid is evaluated using the ion chelating assay [40]. The activity is measured by monitoring the decrease in absorbance of red ferric-Ferrozin complex as antioxidants compete with ferrozin complex in chelating ferrous ion [41]. As shown in Figure 7, AEFF samples showed the highest chelating activity (26.28\%) followed by AEDF (18.34\%), AESF (13.41\%), AEZF 1 (9.24\%) and $\mathrm{AEZF}_{3}$ (6.17\%), respectively. It is clear that chelating power of fresh samples (AEFF) of $I$. herbstii flower was higher as compared with the other samples which may be due to its higher anthocyanin content. Therefore the chelating power of anthocyanin extracts increase with increase in its content of anthocyanin compounds which are responsible for metal chelating. Lee et al., in the year 2004 reported that non-phenolic metal chelators includes phosphoric acid, carnosin, some amino acids, peptide and proteins such as transferring, ovo-transferrin are responsible for metal chelation. Since in our extracts there are no nonphenolic metal chelators which are responsible for metal chelating [42].

\subsubsection{Determination of Inhibitory Effect on Deoxyribose Degradation}

Hydroxyl radicals can be formed by the Fenton's reaction in the presence of reduced transition metal such as $\mathrm{Fe}^{2+}$ and $\mathrm{H}_{2} \mathrm{O}_{2}$, which is known to be the most reactive of all reduced from of dioxygen and thought to initiate all 


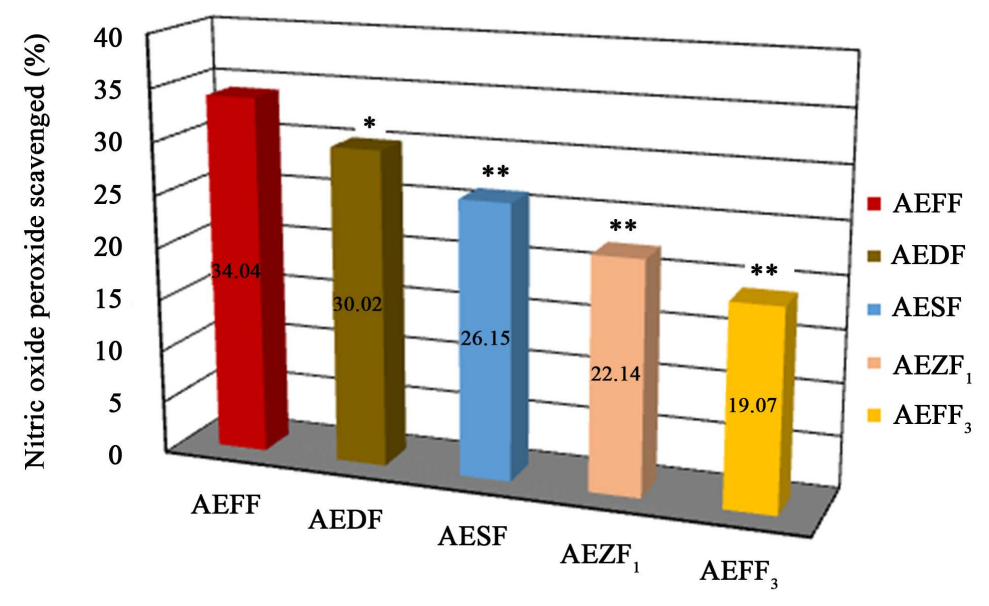

Anthocyanin Extracts

Figure 6. Nitric oxide radical scavenging activity of anthocyanin contents of Iresine herbstii L. flowers (AEIH). Values are mean $\pm \mathrm{SEM},{ }^{*} \mathrm{P}<0.05,{ }^{* *} \mathrm{P}<$ 0.01 , Dunnet test as compared to fresh flower group.

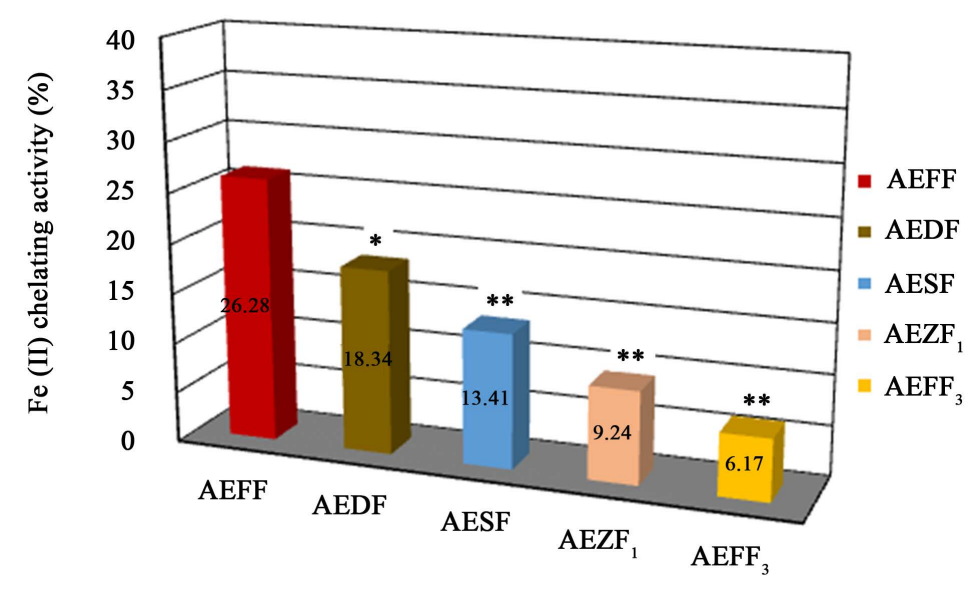

Anthocyanin Extracts

Figure 7. Metal chelating activity of anthocyanin contents of Iresine herbstii L. flowers $(\mathrm{AEIH})$. Values are mean $\pm \mathrm{SEM},{ }^{*} \mathrm{P}<0.05,{ }^{* *} \mathrm{P}<0.01$, Dunnet test as compared to fresh flower group.

damage in vivo [28] [43]. To determine whether I. herbstii flower anthocyanin extract (AEIH) reduce hydroxyl radical generation by chelating metal ions or by directly scavenging hydroxyl radicals, the effects of the anthocyanins on hydroxyl radical generated by $\mathrm{Fe}^{3+}$ ions were analyzed by determining the degree of deoxyribose degradation. The total anthocyanin amount dependent inhibited of hydroxyl radical induced deoxyribose degradation by anthocyanin extract (AEIH) in both the site specific and specific assays. The inhibitory effect of the anthocyanins on deoxyribose degradation was appreciably high in AEFF [38.12\%] followed by AEDF (36.45\%), AESF (32.15\%) and $\mathrm{AEZF}_{1}$ (27.32\%) samples while $\mathrm{AEZF}_{3}$ (17.13\%) sample had the lowest, Figure 8. Generally, $\mathrm{AEZF}_{3}$ sample had the lowest total anthocyanin contents. From the results it was observed that the anthocyanins inhibited deoxyribose degradation mainly by chelating metal ions rather than by scavenging hydroxyl radical directly. Similar results were reported for extracts of Litchi chinenesis Sonn. [44] and Sesbania sesban [45].

\section{Conclusion}

From the results obtained in the present study, it may be concluded that the flowers of Iresine herbstii L. could 


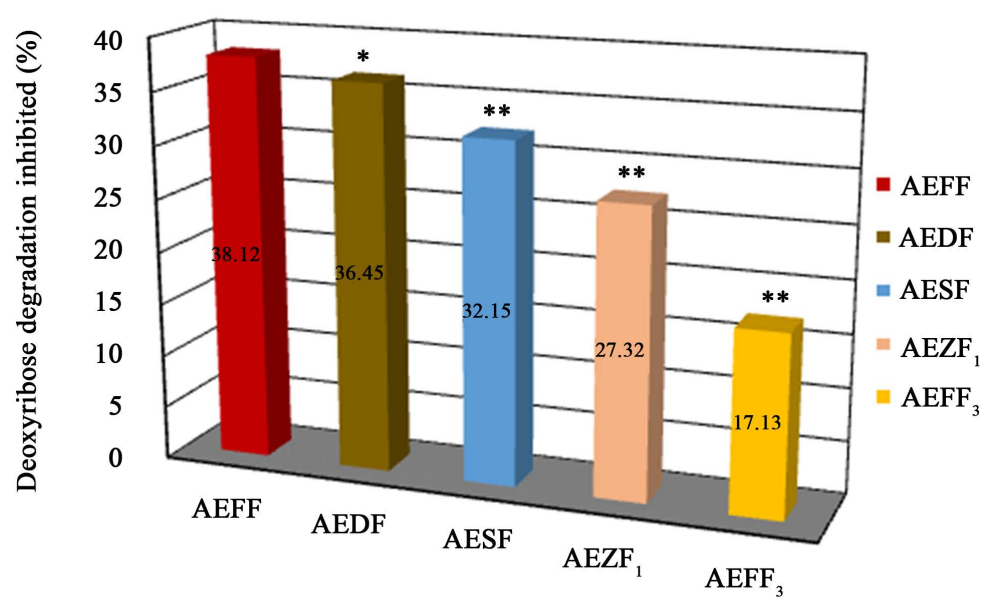

Anthocyanin Extracts

Figure 8. Inhibitory effect on deoxyribose degradation of anthocyanin contents of Iresine herbstii L. flowers (AEIH). Values are mean \pm SEM, ${ }^{*} \mathrm{P}<$ $0.05,{ }^{* *} \mathrm{P}<0.01$, Dunnet test as compared to fresh flower group.

be evaluated as a majour source of anthocyanin. The amount of total anthocyanin was dramatically losses during vacuum drying, storage and freezing with compared to the fresh samples. The antioxidant profile of these compounds can be harnessed to treat radical related pathological conditions. The mechanism of antioxidant action was based on the ability of its extracts to donate electrons, reduce ferric ions, and scavenge superoxide anion, nitric oxide, hydrogen peroxide, and hydroxyl radicals. Thus this study gives support for expanding future investigations of pharmacological activities associated with free radicals and characterization of potent extract for its main active constituents.

\section{References}

[1] Ponmozhi, P., Geetha, M., Kumar, S.M. and Devi, S.P. (2011) Extraction of Anthocyanin and Analysing Its Antioxidant Properties from Pithecellobium dulce Fruit Pericarp. Asian Journal of Pharmaceutical and Clinical Research, 4, 41-45.

[2] Bouayed, J., Piri, K., Rammal, H., Dicko, A., Desor, F., Younos, C. and Soulimani, R. (2007) Comparative Evaluation of the Antioxidant Potential of Some Iranian Medicinal Plants. Food Chemistry, 104, 364-368. http://dx.doi.org/10.1016/j.foodchem.2006.11.069

[3] Wang, H., Cao, G. and Prior, R.L. (1997) Oxygen Radical Absorbing Capacity of Anthocyanins. Journal of Agricultural and Food Chemistry, 45, 304-309. http://dx.doi.org/10.1021/jf960421t

[4] Andersen, Ø.M. and Jordheim, M. (2006) The Anthocyanins. In: Andersen, O.M. and Markham, K.R., Eds., Flavonoids Chemistry, Biochemistry and Applications, CRC Press, Taylor and Francis, Boca Raton, 471-551.

[5] Meskin, M.S., Bidlack, W.S., Davis, A.J., Lewis, D.S. and Randolph, K. (2004) Phytochemicals: Mechanisms of Action. Taylor \& Francis, Boca Raton.

[6] Bride, P. and Timberlake, C.F. (1997) Anthocyanin as Natural Food Colours Selected Aspects. Food Chemistry, 58, 103-109. http://dx.doi.org/10.1016/S0308-8146(96)00222-1

[7] Malien-Aubert, C., Dangles, O. and Amiot, M.J. (2001) Color Stability of Commercial Anthocyanin-Based Extracts in Relation to the Phenolic Composition. Protective Effects by Intra- and Intermolecular Copigmentation. Journal of Agricultural and Food Chemistry, 49, 170-176. http://dx.doi.org/10.1021/jf0007910

[8] Parisa, S., Haidari, R.H., Elham, G. and Rashid, J. (2007) Effect of Heating, UV Irradiation and pH on Stability of the Anthocyanin Copigment Complex. Pakistan Journal of Biological Sciences, 10, 267-272. http://dx.doi.org/10.3923/pjbs.2007.267.272

[9] Sadilova, E., Stintzing, F.C., Kammerer, D.R. and Carle, R. (2009) Matrix Dependent Impact of Sugar and Ascorbic Acid Addition on Color and Anthocyanin Stability of Black Carrot, Elderberry and Strawberry Single Strength and from Concentrate Juices upon Thermal Treatment. Food Research International, 42, 1023-1033. http://dx.doi.org/10.1016/j.foodres.2009.04.008 
[10] De-Feo, V. (2003) Ethnomedical Field Study in Northern Peruvian Andes with Particular Reference to Divination Practices. Journal of Ethnopharmacology, 85, 243-256. http://dx.doi.org/10.1016/S0378-8741(03)00017-5

[11] Bianchi, A. and Samorini, G. (1993) Plants in Association with Ayahuasca. Yearbook for Ethnomedicine and the Study of Consciousness, 2, 21-42.

[12] Schultes, R.E. and Hofmann, A. (1973) The Botany and Chemistry of Hallucinogens. Charles C Thompson, Springfield, 226.

[13] Srithi, K., Balslev, H., Wangpakapattanawong, P., Srisanga, P. and Trisonthi, C. (2009) Medicinal Plant Knowledge and Its Erosion among the Mien (Yao) in Northern Thailand. Journal of Ethnopharmacology, 123, 335-342. http://dx.doi.org/10.1016/j.jep.2009.02.035

[14] Khare, C.P. (2007) Indian Medicinal Plants: An Illustrated Dictionary. Springer, New York, 12.

[15] Vicente, T., Malagón, O., Finzi, P.V., Vidari, G., Armijos, C. and Zaragoza, T. (2007) An Ethnobotanical Survey of Medicinal Plants Used in Loja and Zamora-Chinchipe, Ecuador. Journal of Ethnopharmacology, 111, 63-81.

[16] Lohachoompol, V., Srzednicki, G. and Craske, J. (2004) The Change of Total Anthocyanins in Blueberries and Their Antioxidant Effect after Drying and Freezing. Journal of Biomedicine and Biotechnology, 2004, 248-252. http://dx.doi.org/10.1155/S1110724304406123

[17] Garciia-Viguera, C., Zafrilla, P. and Tomás-Barberán, F.A. (1997) Determination of Authenticity of Fruit Jams by HPLC Analysis of Anthocyanins. Journal of the Science of Food and Agriculture, 73, 207-213. http://dx.doi.org/10.1002/(SICI)1097-0010(199702)73:2<207::AID-JSFA703>3.0.CO;2-8

[18] Lee, J.M., Durst, R.W. and Wrolstad, R.E. (2005) Determination of Total Monomeric Anthocyanin Pigment Content of Fruit Juices, Beverages, Natural Colorants, and Wines by the pH Differential Method: Collaborative Study. Journal of AOAC International, 88, 1269-1278.

[19] Orak, H.H. (2006) Total Antioxidant Activities, Phonolics, Anthocyanins, Polyphonoloxidase Activities and Its Correlation of Some Important Red Wine Grape Varieties Which Are Grown in Turkey. LWT-Food Science and Technology, 9, $1-7$.

[20] Oyaizu, M. (1986) Studies on Product of Browning Reaction. Antioxidative Activities of Products of Browning Reaction Prepared from Glucoseamine. Japanese Journal of Nutrition and Dietetics, 44, 307-315. http://dx.doi.org/10.5264/eiyogakuzashi.44.307

[21] Siddhurajua, P., Mohanb, P.S. and Beckera, K. (2002) Studies on the Antioxidant Activity of Indian Laburnum (Cassia fistula L.): A Preliminary Assessment of Crude Extracts from Stem Bark, Leaves, Flowers and Fruit Pulp. Food Chemistry, 79, 61-67. http://dx.doi.org/10.1016/S0308-8146(02)00179-6

[22] Singh, R.P., Murthy, K.N.C. and Jayaprakash, G.K. (2002) Studies on the Antioxidant Activity of Pomegranate (Punica granatum) Peel and Seed Extracts Using in Vitro Models. Journal of Agricultural and Food Chemistry, 50, 81-86. http://dx.doi.org/10.1021/jf010865b

[23] Akinpelu, D.A., Aiyegoro, O.A. and Okoh, A.I. (2010) The in Vitro Antioxidant Property of Methanolic Extract of Afzelia Africana (Smith.). Journal of Medicinal Plant Research, 4, 2021-2027.

[24] Susuanta, K.M., Goutham, C., Gupta, M. and Mazumdar, U.K. (2006) In Vitro Antioxidant Activity of Diospyros Malabarica Kostel Bark. Indian Journal of Experimental Biology, 44, 39-44.

[25] Lee, J.C., Kim, H.R., Kim, J. and Jang, Y.S. (2002) Antioxidant Property of an Ethanol Extracts of the Stem of Opuntia ficusindica var. Saboten. Journal of Agricultural and Food Chemistry, 50, 6490-6496. http://dx.doi.org/10.1021/jf020388c

[26] García-Viguera, C., Zafrilla, P., Artés, F., Romero, F., Abellán, P. and Tomás-Barberán, F.A. (1998) Colour and Anthocyanin Stability of Red Raspberry Jam. Journal of the Science of Food and Agriculture, 78, 565-573. http://dx.doi.org/10.1002/(SICI)1097-0010(199812)78:4<565::AID-JSFA154>3.0.CO;2-P

[27] Poinana, M., Moigradean, D., Raba, D., Alda, L. and Popa, M. (2010) The Effect of Long-Term Frozen Storage on the Nutraceutical Compounds, Antioxidant Properties and Color Indices of Different Kinds of Berries. Journal of Food, Agriculture and Environment, 8, 54-58.

[28] Elakkiya, S., Pallavi, R., Tennety, S.R. and Suganyadevi, P. (2012) To Evaluate in Vitro Antioxidant Property of Sugarcane (Saccharum officinarum L.) Peel. International Journal of Pharma and Bio Sciences, 3, B65-B73.

[29] Rabeta, M.S. and Lai, S.Y. (2013) Effects of Drying, Fermented and Unfermented Tea of Ocimum tenuiflorum Linn. on the Antioxidant Capacity. International Food Research Journal, 20, 1601-1608.

[30] Basu, S., Roychoudhury, A., Sanyal, S. and Sengupt, D.N. (2012) Carbohydrate Content and Antioxidative Potential of the Seed of Three Edible Indica Rice (Oryza sativa L.) Cultivars. Indian Journal of Biochemistry \& Biophysics, 49, 115-123.

[31] Al-Fartosy, A.J.M. (2011) Antioxidant Properties of Methanolic Extract of Inula graveolens L. Turkish Journal of 
Agriculture and Forestry, 35, 591-596.

[32] Oboh, G. (2008) Polyphenol Extracts from Hyptis suaveolens Leaves Inhibit $\mathrm{Fe}^{2+}$-Induced Lipid Peroxidation in Brain. International Journal of Biomedical and Pharmaceutical Sciences, 2, 41-46.

[33] Olanlokun, J.O. and Akomolafe, S.F. (2013) Antioxidant Potentials of Various Solvent Extracts from Stem Bark of Enantia chlorantha. Journal of Biomedical Science and Engineering, 6, 877-884. http://dx.doi.org/10.4236/jbise.2013.69107

[34] Bloknina, O., Virolainene, S. and Fagersdtedt, K.V. (2003) Antioxidants, Oxidative Damage and Oxygen Deprivation Stress: A Review. Annals of Botany, 91, 179-194. http://dx.doi.org/10.1093/aob/mcf118

[35] Meyar, A.S. and Isaksen, A. (1995) Application of Enzymes as Food Antioxidants. Trends in Food Science \& Technology, 6, 300-304. http://dx.doi.org/10.1016/S0924-2244(00)89140-2

[36] Chang, L.W., Yen, W.J., Huang, S.C. and Duh, P.D. (2002) Antioxidant Activity of Sesame Coat. Food Chemistry, 78, 347-354. http://dx.doi.org/10.1016/S0308-8146(02)00119-X

[37] Paździoch-Czochra, M. and Wideńska, A. (2002) Spectrofluorimetric Determination of Hydrogen Peroxide Scavenging Activity. Analytica Chimica Acta, 452, 177-184. http://dx.doi.org/10.1016/S0003-2670(01)01455-6

[38] Gülçin, I. (2006) Antioxidant and Antiradical Activities of L-Carnitine. Life Sciences, 78, 803-811. http://dx.doi.org/10.1016/j.lfs.2005.05.103

[39] Ashokkumar, D., Thamilselvan, V., Senthilkumar, G.P., Mazumder, U.K. and Gupta, M. (2008) Antioxidant and Free Radical Scavenging Effects of Lippia nodiflora. Pharmaceutical Biology, 46, 762-771. http://dx.doi.org/10.1080/13880200802315444

[40] Hsu, C., Hsu, L., Chen, W., Weng, Y.M. and Tseng, C.Y. (2003) Chemical Composition, Physical Properties and Antioxidant Activities of Yam Flowers as Affected by Different Drying Methods. Food Chemistry, 83, 85-92. http://dx.doi.org/10.1016/S0308-8146(03)00053-0

[41] Elmasar, M., Guluin, I., Isildak, O., Kutreuioglu, O.I., Ibaoglu, K. and Aboul-Enein, H.Y. (2006) Radical Scavenging Activity and Antioxidants Capacity of Bay Leaf Extracts. Journal of the Iranian Chemical Society, 3, 258-266.

[42] Lee, J., Koo, N. and Min, D.B. (2004) Reactive Oxygen Species, Aging and Antioxidative Nutraceuticals. Comprehensive Reviews in Food Science and Food Safety, 3, 21-33. http://dx.doi.org/10.1111/j.1541-4337.2004.tb00058.x

[43] Rollet-Labelle, E., Grange, M.J., Elbim, C., Marquetly, C., Gougerot-Pocidalo, M.A. and Pasquier, C. (1998) Hydroxyl Radical as a Potential Intracellular Mediator of Polymorphonuclear Neutrophil Apoptosis. Free Radical Biology and Medicine, 24, 563-572. http://dx.doi.org/10.1016/S0891-5849(97)00292-X

[44] Duan, X.W., Jiang, Y.M., Su, X.G., Zhang, Z.Q. and Shi, J. (2007) Antioxidant Properties of Anthocyanins Extracted from Litchi (Litchi chinenesis Sonn.) Fruit Pericarp Tissues in Relation to Their Role in the Pericarp Browning. Food Chemistry, 101, 1365-1371. http://dx.doi.org/10.1016/j.foodchem.2005.06.057

[45] Kathiresh, M., Suganya, P. and Saravanakumar, M. (2011) Antioxidant Effect of Sesbania sesban Flower Extract. International Journal of Pharmaceutical Sciences, 3, 1307-1312. 